\title{
The effects of life style modification versus food supplementation on menopausal symptoms
}

\author{
Suzanne Fouad ${ }^{1 *}$ D, Salwa Mostafa El Shebini ${ }^{1}$, Nihad Hassan Ahmed ${ }^{1}$, Ahmed Mohamed Saied Hussein², \\ Hend Abbas Essa', Maha Abdel-Moaty and Salwa Tawfic Tapozada'
}

\begin{abstract}
Background: Nutrition and good health are two dependent parallel axes; female's health at different ages in general and at the time of menopause in particular has received a lot of attention last several years. The objective of this experimental study was to evaluate the effect of consuming food supplement versus lifestyle modification in the dietary habit on menopausal symptoms in perimenopausal Egyptians females.

Results: Forty seven females in the perimenopausal stage of life with mean age $46.04 \pm 5.88$ years participated on the food supplement consumption group, they consumed $75 \mathrm{~g}$ per day of a rusk (prepared from corn flour, wheat flour $72 \%$, full cream milk powder, flaxseed oil, wheat germ, clove and cinnamon powder) for 2 months. They were compared with the control group (forty nine females with mean age $46.91 \pm 5.39$ years) who changed their foods habits to a healthy life style. Menopause rating scale and the biochemical analysis were comparable on day 1 and on day 60 . The total menopause rating scale and its three subscales (psychological, urogenital and somatic), waist circumference, serum follicle stimulating hormone and estradiol in the corn rusk supplement group showed a statistically significant improvement. No significant difference was noted in the control group apart of the psychological subscale and waist circumference.
\end{abstract}

Conclusions: Corn Rusk enriched with clove and cinnamon as a food supplement snake is promising to relief menopausal symptoms and should be considered on the diet of menopausal females.

Keywords: Menopause, Corn flour, Clove, Cinnamon, Life style modifications

\section{Background}

The menopause symptoms are experienced by 1.5 million women each year; symptoms including hot flashes, night sweats, sleep disturbances, sexual dysfunction, urological symptoms, mood disorders, psychological problems, cognitive declines, weight gain, joint and muscle aches (El Khoudary et al. 2019; Sussman et al. 2015).

Phytoestrogens or plant estrogens are plant compounds that are capable to bind to estrogen receptors in the

\footnotetext{
*Correspondence: suzannefouad6161@yahoo.com

${ }^{1}$ Nutrition and Food Science Department, National Research Center,

El-Bohoth St, Dokki, Cairo Postal Code: 12622, Egypt

Full list of author information is available at the end of the article
}

body cells (Lecomte et al. 2017). They are found in certain foods and can replace to some extent the effects of estrogen that is decreased with menopause. Phytoestrogens mimic the functions of estrogens on females' body (Kuhnle et al. 2009). It is well known that soya products are good source of phytoestrogen (Barrette 2006), and eating bakery product prepared from soya flour helps in ameliorating the severity of various menopausal symptoms (Fouad et al. 2018). Moreover, El Shebini et al. (2020) demonstrated the positive impact of consuming a blend composed of peanut, sesame, coriander and thyme on relieving the somatic and psychological symptoms on perimenopausal women. 
Corn is a source of corn flour and corn starch; both are different in their nutrient values and uses. Corn flour results from grinding whole corn kernels into yellow fine powder. Corn flour is rich on protein, starch, fiber, vitamins $B$ and minerals as iron, potassium and magnesium; it is used to make breads and pastries. While, corn starch is more refined white powder and results from subtraction of the corn kernel which contains the protein and fiber, leaving only the endosperm which contains the starch. Corn starch is used as a thickening agent (Wineinger et al. 2013).

Cloves are the aromatic flowers; they were used mainly on the ancient medicine for toothache due to their high content of eugenol clove oil (Kamatou et al. 2012). Nowadays, cloves proved to have several biological benefits such as antioxidant activity as free radical scavenging, antimicrobial, antifungal, antiapoptotic and analgesic properties (Mittal et al. 2014).

Cinnamon belongs to the lauraceae family; it is rich on phenolic compounds which has an antioxidant, antiinflammatory and antibacterial activity (Mishra and Srivastava 2020; Cao et al. 2008).

The objective of this study is to assess the effectiveness of consuming prepared corn rusk enriched with cinnamon and clove versus lifestyle modification in the dietary management of menopausal symptoms in perimenopausal Egyptians females.

\section{Methods}

This is an experimental study, using a purposive sampling method. Based on previous study, representative sample was chosen. Subjects were divided into two groups including 47 and 49 volunteers' women in groups (1) and (2) respectively, which were adequate to achieve $95 \%$ power to detect difference between group proportions. The inclusion criteria were females with menopausal symptoms on the perimenopause (menopause transition) phase of life, who were recruited from the attendants at nutrition and food sciences department of NRC at Egypt. Participants must be complaining of menopausal symptoms as hot flushes, night sweats, vaginal dryness, mood swing and other different symptoms as evaluated by menopause rating scale (MRS), and confirmed diagnosis of menopause was done by biochemical assessment of serum Follicle Stimulating Hormone level $\geq 30 \mathrm{mIU} /$ $\mathrm{mL}$. Women who did not fit this particular profile were excluded. Full medical history and clinical examination were evaluated to exclude subjects with thyroid, renal or hepatic diseases and anemia.

Participants were randomly divided into two groups, each group included 50 volunteers' women (group I and group II); Participants were randomized in a 1:1 allocation ratio using a computer-generated random number table. All subjects were informed not to use estrogen replacement therapy throughout the study. Signed written informed consents were taken from the women after full explanation of the study to participate in the research study. Weekly interview follow up of the perimenopausal women during the study period was regularly done.

The scoring of the MRS was calculated by questionnaire of different menopausal symptoms, with different degrees of severity of symptoms presented by points from 0 to 5 for each question (Schneider et al. 2000). The questionnaires were asked by easy sentences on oral Arabic language by the same investigator (translated on the sheet forum from the English version of the scale by the same physician to prevent double or different translations). The composite total score was the sum of the psychological, somatic, and urogenital subscales. Somatic symptoms included hot flushes, night sweating, awareness of cardiac pulsation, sleep problems, articular and muscular ache. Psychological symptoms involved depression, irritability, anxiety, mood daily change and cognitive dysfunctions. Urogenital symptoms included three main axes (sexual, bladder and vaginal symptoms).

Dietary recalls of food intake last $24 \mathrm{~h}$ was recorded on group (II) on day one and day 60; analysis of data collected was done using World Food Dietary Assessment System (W- FOOD2 program) USA, University of California, 1995.

Blood sampling and biochemical analysis was performed to assess the female sex hormones levels by quantitative determination of hormones concentration in participants' sera; Follicle Stimulating Hormone (FSH) by FSH ELISA kit of ChemuxBioScienceInc, USA., cata$\log$ number 10001, the procedure was done according to (Rebar et al. 1982); Estradiol E2 ELISA kit of ChemuxBioScienceInc, USA., catalog number 10009 according to (Ratcliffe et al. 1988); Free Testosterone concentration by Free Testosterone ELISA kit of IBL GMBH, Germany, catalog number EFT127 according to (Swerdloff and Wang 2008); progesterone concentration by progesterone ELISA kit of Chemux BioScience Inc, USA., catalog number 10004.11 according to (March et al. 1979).

\section{Group I: subjects treated by the prepared food supplement} Females in this group consumed a supplement prepared from corn flour, wheat flour $72 \%$, full cream milk powder, flaxseed oil, wheat germ, clove and cinnamon powder that was made in the form of Rusk; they consumed five Rusk daily ( $75 \mathrm{~g} /$ five rusk/day) for 8 weeks. Food supplement (corn rusk) was standard manufactured all through the intervention at the production unit at NRC, by mixing the ingredients listed on Table 1 according to (AACC 2000), and baked in an electrical oven at $200{ }^{\circ} \mathrm{C}$ for about 
Table 1 Formula composition of Corn Rusk (percentage of ingredients)

\begin{tabular}{ll}
\hline Ingredients & Formula (\%) \\
\hline Corn Flour & 55 \\
Wheat flour (72\%) & 10 \\
Full Cream Milk Powder & 10 \\
Flax seed oil & 10 \\
Wheat germ & 5 \\
Cinnamon Powder & 3.5 \\
Crushed clove & 3 \\
Cumin seed & 2 \\
Egg & 0.5 \\
Baking powder & 0.75 \\
Latency & 0.25 \\
\hline
\end{tabular}

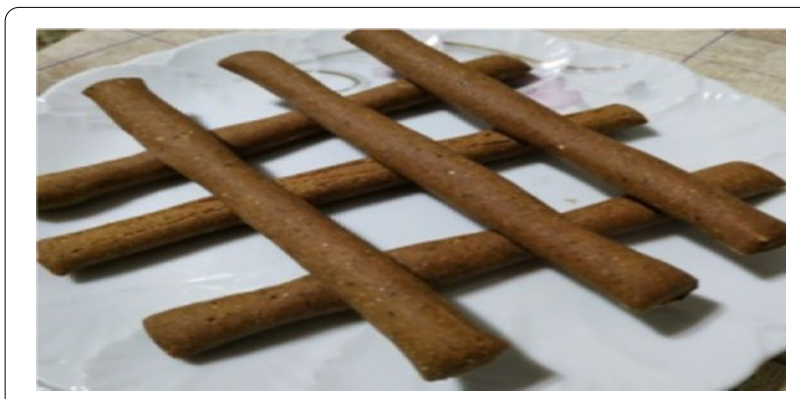

Fig. 1 Corn rusk

20 min (Fig. 1). All ingredients were bought from the same market all through the study.

Ash, macronutrients contents were determined in the Rusk according to (AOAC 2000). Total phenolic content was determined according to laboratory procedure described by $\mathrm{Xu}$ and Chang (2007). The sensory evaluation of corn rusk was carried out with some modification, according to (Dijksterhuis et al. 2007) by 15 trained panelists; the tests characteristics were Color (20), odor (20), taste (20), crispiness (20), appearance (20) and overall acceptability (100).

\section{Group II: subjects treated by the changing their food habits as a control group}

These participants underwent a combined intervention of diet and exercise. No vitamins or other nutritional supplements were prescribed although the study. Foods recommended to the menopausal women on group II to be consumed and avoided during the study period were described as follow. Eat complex carbohydrates of low glycemic load such as barley, oat, corn and brown rice, with decrease uptake of simple carbohydrate as white sugar and deserts. Eat daily good source of fiber and minerals as fresh seasonal fruits and vegetables instead of a sugary dessert. Eat foods rich in unsaturated fatty acids as Salmon, mackerel, sardines and tuna; we recommended them to use virgin olive oil and flaxseed oil. Concerning protein uptake, we advised the subjects to consume protein rich foods containing the tryptophan, an essential amino acids important in fighting depression commonly present with menopause, tryptophan is found in legumes, cottage cheese, turkey, beans and lentils. They must avoid fried foods, bagged, processed and red meats. To maintain bone health, we advised them to walk half an hour (4 times/week at 11:00 AM), with consuming food rich on calcium, vitamin D and vitamin $\mathrm{K}$ (milk products, sardine, mushroom, egg, dark green leafy vegetables, nuts, apples, pears, grapes, dates and raisins). Limit intake of caffeine, salt and soda drink. Wear cotton clothing, avoid hot humid weather as possible, drink plenty of water and sleep early and at least $6 \mathrm{~h}$ per night.

Finally we advise them to keep a note about their symptoms following eating, drinking or new wears when each hot flush began to avoid the documented trigger (any food, beverages or clothes that predisposed to hot flush attack). Patients on group II wrote seven sheets per week (given to them) about what they ate and drink per day; amount, type, method of preparation of food, time of eating, and place of eating (at home, work, restaurant,...).

\section{Statistical analysis}

The data collected of the two groups before and after the interventions were calculated, compared, and analyzed. Descriptive results for different variables are expressed as mean $\pm S D$ and/or percentage. Independent-samples $t$ tests or Mann-Whitney $U$ tests were used as appropriate for comparison between the two groups as well as to compare each group before and after intervention. Significance was defined at the $p$ value $<0.05$. Analysis was performed using SPSS version 16 (SPSS Inc. Chicago, IL).

\section{Results}

Initially fifty subjects were targeted for each group; forty seven volunteers' women completed the study in group (I) with mean age $46.04 \pm 5.88$ years, while forty nine volunteers' women completed the study on group (II) with mean age $46.91 \pm 5.39$ years. Four patients on both groups didn't complete the study period as they were not tighter to the project protocol; three on group (I) didn't consume the amount of corn rusk as prescribed to them and one subject on group II didn't follow the instructions, she didn't represent the follow up sheets on the weekly interview. Table 2 showed the chemical composition of the daily consumed corn rusk, the percentage of macronutrients including carbohydrates, proteins, fats, and the fiber content were adequate; the rusk was a good source of protein, fiber 
and total phenols which was estimated as an indicator of phytoestrogen content $(5348.61 \mathrm{mcg} / 100 \mathrm{~g})$. Regarding sensory evaluation for characteristics color, flavor, taste, crispiness, appearance and overall acceptability, it could be noticed that corn rusk was acceptable (Table 3).

Table 4 demonstrated the mean \pm SD and the percent of the Recommended Daily Allowances (\% RDAs) of the

Table 2 Chemical composition of corn rusk

\begin{tabular}{|c|c|c|c|c|c|c|}
\hline Sample & Ash \% & Protein \% & Fat $\%$ & Fiber \% & Total carbohydrate $\%$ & Total phenols (mcg/ $100 \mathrm{~g})$ \\
\hline Corn Rusk & $1.92 \pm 0.01$ & $10.23 \pm 0.09$ & $20.46 \pm 0.12$ & $11.62 \pm 0.05$ & $55.77 \pm 0.55$ & 5348.61 \\
\hline
\end{tabular}

Table 3 Sensory evaluation of the corn supplement

\begin{tabular}{|c|c|c|c|c|c|c|}
\hline Sample & Color (20) & Odor (20) & Taste (20) & Crispiness (20) & Appearance (20) & Overall acceptability (100) \\
\hline Corn Rusk & $18.12 \pm 1.13$ & $19.12 \pm 0.96$ & $19.0 \pm 1.10$ & $18.11 \pm 0.85$ & $17.55 \pm 0.66$ & $91.90 \pm 2.65$ \\
\hline
\end{tabular}

Table 4 Mean \pm SD of the daily nutrients intake and the RDAs percent for women on group II

\begin{tabular}{|c|c|c|c|}
\hline Group II & Before diet modification & After diet modification & RDAs \\
\hline Nutrient Intake & $\begin{array}{l}\text { Mean } \pm \text { SD } \\
\% \text { RDAs }\end{array}$ & $\begin{array}{l}\text { Mean } \pm \text { SD } \\
\% \text { RDAs }\end{array}$ & \\
\hline Energy (kcal) & $\begin{array}{l}2458.23 \pm 34.52^{* *} \\
111.74\end{array}$ & $\begin{array}{l}1267.22 \pm 31.15 \\
57.60\end{array}$ & $\begin{array}{l}\text { Depend on age, sex, weight } \\
\text { and physical activity }\end{array}$ \\
\hline Protein (g) & $\begin{array}{l}76.46 \pm 14.52^{* *} \\
152.64\end{array}$ & $\begin{array}{l}48.11 \pm 12.17 \\
96.22\end{array}$ & 50 \\
\hline Carbohydrate(g) & $\begin{array}{l}238.864 \pm 30.72^{*} \\
83.64\end{array}$ & $\begin{array}{l}166.86 \pm 20.16 \\
55.62\end{array}$ & 300 \\
\hline Dietary fiber (g) & $\begin{array}{l}21.01 \pm 10.12 \\
80.56\end{array}$ & $\begin{array}{l}21.15 \pm 4.10 \\
84.60\end{array}$ & 25 \\
\hline Fat (g) & $\begin{array}{l}112.26 \pm 14.26^{* *} \\
145.79\end{array}$ & $\begin{array}{l}45.26 \pm 14.12 \\
58.78\end{array}$ & 77 \\
\hline SFA (g) & $\begin{array}{l}50.89 \pm 5.14^{* *} \\
18.63\end{array}$ & $\begin{array}{l}12.20 \pm 4.51 \\
8.66\end{array}$ & max. $7 \%$ of total energy intake \\
\hline MUFA (g) & $8.19 \pm 3.51$ & $13.14 \pm 2.10^{*}$ & \\
\hline PUFA (g) & $6.52 \pm 5.20$ & $11.69 \pm 2.13^{*}$ & \\
\hline Cholesterol (mg) & $\begin{array}{l}423.12 \pm 33.14^{* *} \\
141.04\end{array}$ & $\begin{array}{l}243.58 \pm 23.24 \\
81.19\end{array}$ & 300 \\
\hline Vit. A $(\mu \mathrm{g})$ & $\begin{array}{l}616.55 \pm 38.19 \\
77.07\end{array}$ & $\begin{array}{l}668.24 \pm 26.17 \\
83.53\end{array}$ & 800 \\
\hline Vit. D ( $\mu \mathrm{g})$ & $\begin{array}{l}2.01 \pm 1.05 \\
40.20\end{array}$ & $\begin{array}{l}3.60 \pm 1.04^{*} \\
72.00\end{array}$ & 5 \\
\hline Sodium (mg) & $\begin{array}{l}1639.32 \pm 22.34^{*} \\
109.29\end{array}$ & $\begin{array}{l}1209.30 \pm 23.17 \\
80.62\end{array}$ & 1500 \\
\hline Potassium (mg) & $\begin{array}{l}1944.39 \pm 21.36 \\
97.22\end{array}$ & $\begin{array}{l}2249.82 \pm 32.60 \\
112.49\end{array}$ & 2000 \\
\hline Calcium (mg) & $\begin{array}{l}641.45 \pm 23.19 \\
53.45\end{array}$ & $\begin{array}{l}925.94 \pm 30.12^{*} \\
77.16\end{array}$ & 1200 \\
\hline Iron (mg) & $\begin{array}{l}6.16 \pm 1.32 \\
41.07\end{array}$ & $\begin{array}{l}8.76 \pm 2.11 \\
58.40\end{array}$ & 15 \\
\hline Zinc (mg) & $\begin{array}{l}6.49 \pm 1.11 \\
54.08\end{array}$ & $\begin{array}{l}6.96 \pm 2.19 \\
58.00\end{array}$ & 12 \\
\hline
\end{tabular}

[RDAs: Recommended Dietary Allowance (Dwyer 2003)]

* Significant at $p \leq 0.05$

*** High significant at $p \leq 0.01$ 
habitual nutrient intake of the studied subjects on group (II), and after following diet modification and health life style for 60 days. When compared to RDAs, the percent daily intake of the calories and the macronutrients (protein, carbohydrate and fat) of the habitual diet were high. The calorie consumed was mainly from fat $(145.79 \%$ of the RDAs) which was high in the saturated fat, low in monounsaturated fatty acids (MUFAs) and polyunsaturated fatty acids (PUFAs). Their diet was deficient in fiber, vitamin A, vitamin D, calcium, iron and zinc, with increase sodium intake compared to the RDAs. After diet modification, the mean caloric intake, the means of the macronutrients and their percent to the RDAs was improved; there was decrease in saturated fatty acid, cholesterol and salt intakes, with increased intake of unsaturated fatty acids, calcium, iron and vitamin $\mathrm{D}$.

Data presented as mean \pm SD of menopausal symptoms score before and after interventions on the two groups could be demonstrated on Table 5, all scores of both groups were comparable at baseline. After sixty days of dietary interventions, all participants on group (I) consuming corn rusk supplement showed marked significant improvement in total MRS and the three subscales; psychological symptoms, urogenital symptoms and somatic menopausal symptoms. Women feels decreased frequency of hot flushes and night sweats, improvement of irritability, anxiety, depressed mood, difficulty sleeping, vaginal dryness and decreased libido. While patients on group (II) showed significant improvement on psychological subscale after lifestyle modification (irritability and moods swings), concerning somatic subscale, the muscle pain decreased but without statistical significance. Waist circumference decreased on both groups, but with statistical significance on group (I). FSH and E2 hormones improved on food supplement group.

\section{Discussion}

Menopause is a natural phenomenon in all women, it is usually occurs due to decline in ovarian sex hormonal secretion; worldwide, 1.2 billion women will become menopause by the year 2030 (Freeman et al. 2007). The associated somatic and psychological symptoms may persist for 15 years or more lately on $12 \%$ of women (Politi et al. 2008; Freeman et al. 2011). Zeleke et al. (2016) reported that one-third of women aged over 65 years report vasomotor symptoms 11 years after the final menstrual period.

In this study, women consumed corn rusk enriched with cinnamon and clove for 60 days reported significant improvements in menopausal symptoms which were assessed by the MRS, there were significant reductions in total score and all the subscales symptoms; the somatic, psychological and urogenital symptoms. Hot flushes and night sweating improved with food supplement over the course of the study. This bakery product as demonstrated by the chemical compositions was rich in dietary total phenols and unsaturated fatty acids. Phytoestrogens including isoflavonoids are nonsteroidal plant-derived compounds have estrogen like effects; Phytoestrogens' similarity to estrogen female sex hormone means they can act on estrogen receptors in different cells to provoke estrogen's functions within the body. Therefore they are able to reduce symptoms related to estrogen loss such as hot flushes, night sweating and others (Lethaby et al. 2013).

Around the world, corn is a component of the diet of all socioeconomic classes and is an excellent source of bioactive compounds such as lignans, carotenoids and phytosterols (Sheng et al. 2018; Harrabi et al. 2008).

The corn rusk decreased waist circumference, psychological and urogenital symptoms significantly; previous studies demonstrated that cinnamon decreased gastric emptying rate and significantly slowed the rise in blood sugar levels. In addition, cinnamon has been used for relieving flatulence, diarrhea and nausea. The cinnamon has several health benefits especially its anti-microbial activity to support the immune system and the antifungal property to stop common yeast growth mainly Candida. Cinnamon enhanced cognitive processing and improved scores related to attention, memory and concentration (Mishra and Srivastava 2020; Hamidpour et al. 2015). Functional foods prepared by different formulae containing active ingredients enhance mental health; barley bread enriched with turmeric or ginger improved the cognitive functions (Moaty et al. 2015). Vaginal candidasis is common in females on the perimenopause phase of life (Hoffmann et al. 2014).

Cloves was known in traditional Chinese medicine to reduce inflammation, relieve pain, improve digestion and to inhibit microorganism growth as clove contains a large number of effective components mainly eugenol. Therefore, the application of clove in food industry as antiseptic attracts attention of many researchers (Batiha et al. 2020; Jessica Elizabeth et al. 2017; Patel 2015; CortésRojas et al. 2014; Pinto et al. 2009; Nassar et al. 2007).

The present study demonstrated that the group treated with life style modification exhibited only a significant improvement in psychological symptoms and waist circumference, it should be mentioned that the present study is limited by its short duration. A previous study reported that women who need relief for vasomotor symptoms, The North American Menopause Society (2004) recommended considering lifestyle changes combined with dietary isoflavones.

Previous studies supported the importance and benefit of physical activity on mood improvement and weight 
Table 5 Mean \pm SD of age, menopausal symptoms and female sex hormones among studied groups before and after dietary interventions

\begin{tabular}{|c|c|c|c|c|c|c|}
\hline \multirow[t]{3}{*}{ Parameters } & \multicolumn{3}{|c|}{ Group I (no. = 47) } & \multicolumn{3}{|c|}{ Group II (no. =49) } \\
\hline & \multicolumn{2}{|l|}{ Mean $\pm S D$} & \multirow[t]{2}{*}{$\%$ change } & \multicolumn{2}{|l|}{ Mean $\pm S D$} & \multirow[t]{2}{*}{$\%$ change } \\
\hline & Before & After & & Before & After & \\
\hline Age (years) & $46.04 \pm 5.88$ & & - & $46.91 \pm 5.39$ & & - \\
\hline Hot flushes (Freq/week) & $10.60 \pm 2.77$ & $1.57 \pm 1.10^{* * a}$ & -85.19 & $12.08 \pm 2.93$ & $10.07 \pm 2.73$ & $-16.64^{* * c}$ \\
\hline Night sweat (Freq/week) & $9.00 \pm 4.60$ & $1.02 \pm 1.19^{* * a}$ & -88.67 & $9.76 \pm 4.14$ & $9.18 \pm 4.09$ & $-5.94^{* *} c$ \\
\hline Total MRS & $38.17 \pm 5.29$ & $8.17 \pm 3.18^{* * a}$ & -78.60 & $36.4 \pm 6.31$ & $31.2 \pm 5.87$ & $-14.29^{* * c}$ \\
\hline Somatic subscale & $7.06 \pm 3.32$ & $3.01 \pm 1.27^{* * a}$ & -57.36 & $9.22 \pm 3.21$ & $7.17 \pm 3.04$ & $-22.23^{* * c}$ \\
\hline Psychiatric subscale & $9.13 \pm 2.97$ & $1.43 \pm 1.25^{* * a}$ & -84.34 & $8.6 \pm 2.42$ & $4.2 \pm 1.33^{* * b}$ & $-51.16^{* *}$ \\
\hline Urogenital subscale & $8.74 \pm 2.24$ & $2.53 \pm 1.46^{* * a}$ & -71.05 & $8.98 \pm 2.61$ & $8.14 \pm 2.40$ & $-9.35^{* * c}$ \\
\hline Waist circ. (cm) & $97.83 \pm 9.08$ & $84.66 \pm 8.41^{* * a}$ & -13.46 & $96.86 \pm 9.13$ & $94.17 \pm 9.01$ & $-2.78^{* * c}$ \\
\hline $\mathrm{FSH}(\mathrm{mIU} / \mathrm{mL})$ & $82.99 \pm 16.19$ & $42.62 \pm 11.09^{* * a}$ & -48.64 & $84.8 \pm 16.99$ & $79.1 \pm 14.32$ & $-6.72^{* * c}$ \\
\hline Estradiol (pg/mL) & $55.79 \pm 2.31$ & $78.17 \pm 2.42^{* * a}$ & +40.11 & $57.91 \pm 3.64$ & $59.94 \pm 2.92$ & $+3.5^{* * c}$ \\
\hline Free testosterone $(\mathrm{pg} / \mathrm{mL})$ & $1.46 \pm 0.70$ & $1.19 \pm 0.37$ & -18.49 & $1.39 \pm 0.62$ & $1.39 \pm 0.59$ & - \\
\hline progesterone $(\mathrm{ng} / \mathrm{mL})$ & $4.57 \pm 1.57$ & $4.60 \pm 1.78$ & +0.65 & $2.26 \pm 0.93$ & $2.31 \pm 0.44$ & +2.21 \\
\hline
\end{tabular}

${ }^{a}$ Paired $t$-test analysis of studied parameters before and after Rusk consumption in group I

b Paired $t$-test analysis of studied parameters before and after the diet intervention in group II

${ }^{b}$ Comparison of studied parameters after the intervention between the two groups by Independent $t$-test analysis

* Significant at $p \leq 0.05$

** High Significant at $p \leq 0.01$

Interpretation of the calculated score of MRS

Total score of MRS

$\begin{array}{ll}3-11 & \text { Mild } \\ 12-22 & \text { Moderate } \\ 23-33 & \text { Severe } \\ \text { Over } 34 \ldots \text { Very severe }\end{array}$

Somatic subscale

$1-4$ Mild

5-8__ Moderate

9-12__ Severe

Over 13 _ very severe

Psychological subscale

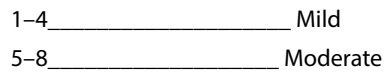

9-12_ Severe

Over 13 Very severe

Urogenital subscale

$\begin{array}{ll}1-3 & \text { Mild } \\ 4-6 & \text { Moderate }\end{array}$

Over $10 \_$Very severe

control, no impact on vasomotor symptoms and urogenital symptoms (Mansikkamaki et al. 2015; Tseng et al. 2012; Moilanen et al. 2010).

Since physical activity is a modified behavior, it is an excellent target for health promotion interventions focused on prevention. Strategies to increase the awareness of the importance of physical activity at the population level to diminish the problem of chronic disease; including reduced risk of hypertension, type II diabetes mellitus, hyperlipidemia, ischemic heart disease, cerebral stroke, obesity, metabolic syndrome, cancer and depression (Tan et al. 2014; Pimenta et al. 2011). 


\section{Conclusions}

What people consume manipulates and controls their body response to the changes it goes through. Rusk prepared from corn, clove and cinnamon improved the symptoms of menopause in perimenopausal women, and the findings of this study suggested that this corn rusk supplement might be a suitable option to relief menopausal symptoms.

\section{Abbreviations}

E2: estradiol; FSH: follicle stimulating hormone; MRS: menopause rating scale; MUFA: monounsaturated fatty acid; PUFA: polyunsaturated fatty acid; RDAs: recommended dietary allowances; SFA: saturated fatty acid; WC: waist circumference.

\section{Acknowledgements}

The authors would like to acknowledge the National Research Centre in Egypt, for project foundation. The Project No."11010188" entitled "Dietary therapy and alternative medicine for alleviating the menopausal symptoms".

\section{Authors' contributions}

SF designed research and was responsible for clinical examination, anthropometrics measurements and weekly follow up; SF wrote manuscript; $\mathrm{NH}$ was responsible for preparation of the supplement and analysis of nutritional intake and dietary habit, HA had responsibility for biochemical analysis and laboratory investigations; SF and $\mathrm{NH}$ were involved in subjects selections, consent signature by the subjects and data collection; AS had the responsibility for chemical analysis of the supplement; MM was responsible for statistical analysis; All authors have read and approved the manuscript; SS revised the final manuscript; SS and ST have primary responsibility for final content. All authors read and approved the final manuscript.

\section{Funding}

The practical part of the work was financial supported by the National Research Centre, Egypt, as a foundation for the Project No. "11010188"entitled "Dietary therapy and alternative medicine for alleviating the menopausal symptoms".

\section{Availability of data and materials}

All data generated or analyzed during this study are included in this published article.

\section{Declarations}

Ethics approval and consent to participate

The research was given ethical approval from Ethical Committee of National Research Centre, (Registration Number is 16/110) and Signed written informed consent from each of the volunteers' women was a must to participate in the research project after they had been given a full explanation of the study.

\section{Consent for publication}

Not applicable.

\section{Competing interests}

The authors declare that there is no conflict of interests regarding the publication of this paper.

\section{Significance statement}

This study revealed the importance of and the healthy beneficial effect of using functional foods rich in bioactive substances in the form of dietary supplements as a dietary strategy to reduce the menopausal symptoms. Although life style modification helps to improve waist circumference but, it didn't affect menopause symptoms apart of psychological symptoms as mood swing and irritability. This study discovers the importance of corn, glove and cinnamon for alleviating the menopausal symptoms in Egyptian females. This study will help the researcher to uncover the role of diet supplement significant in improvement the somatic menopausal symptoms, urogenital symptoms, and psychological symptoms after intervention.

\section{Author details}

${ }^{1}$ Nutrition and Food Science Department, National Research Center, El-Bohoth St, Dokki, Cairo Postal Code: 12622, Egypt. ${ }^{2}$ Food Technology Department, National Research Centre, Dokki, Giza, Egypt.

Received: 18 November 2020 Accepted: 8 March 2021

Published online: 17 March 2021

\section{References}

AACC (2000) Approved Methods of Analysis. 10th Edn., American Association of Cereal Chemists, St. Paul, MN USA., ISBN-13: 9781891127120

AOAC (2000) Official Methods of Analysis of AOAC International (17th Ed.) byHorwitz, W. Suite 500, 481 North Fredric avenue Gaithersburg, Maryland 20877-2417, USA.

Barrette J (2006) The science of soy: What do we really know? Enviromental Health Persepectives 114(6):A352-A358. https://doi.org/10.1289/ ehp.114-a352

Batiha G, Alkazmi L, Wasef L, Beshbishy A, Nadwa E, Rashwan E (2020) Syzygium aromaticum L. (Myrtaceae): traditional uses, bioactive chemical constituents, pharmacological and toxicological activities. Biomolecules 10(2):202-211. https://doi.org/10.3390/biom10020202

Cao H, Urban J, Anderson R (2008) Cinnamon polyphenol extract affects immune responses by regulating anti- and proinflammatory and glucose transporter gene expression in mouse macrophages. J Nutr 138:833-840

Cortés-Rojas D, De Souza C, Oliveira W (2014) Clove (Syzygium aromaticum): a precious spice. Asian Pac J Trop Biomed 4(2):90-96

Dijksterhuis G, Luyten H, De Wijk R, Mojet J (2007) A new sensory vocabulary for crisp and crunchy dry model foods. Food Qual Prefer 18:37-50. https ://doi.org/10.1016/j.foodqual.2005.07.012

Dwyer J (2003) Dietary requirements of adults. Encyclopedia of Food Sciences and Nutrition (Second Edition), pp 1863-1868. https://doi.org/10.1016/ B0-12-227055-X/00350-3

El Khoudary S, Greendale G, Crawford S, Avis N, Brooks M, Thurston R, Karvonen-Gutierrez C, Waetjen L, Matthews K (2019) The menopause transition and women's health at midlife: a progress report from the Study of Women's Health Across the Nation (SWAN). Menopause 26(10):1213-1227. https://doi.org/10.1097/GME.0000000000001424

El Shebini SM, Fouad S, Moaty MI, Ahmed NH, Mohamed MS, Essa HA, Tapozada ST (2020) Dietary supplement for relieving menopausal symptoms in Egyptian perimenopausal women. Bull Natl Res Centre 44:39. https:// doi.org/10.1186/s42269-020-00291-2

Fouad S, El Shebini S, Moaty MI, Ahmed NH, Hussein AS, El Gendy A, Essa HA, Tapozada ST (2018) Nutritional supplement prepared from whole meal wheat flour, soya bean flour, Flaxseed and Anise seeds for alleviating the menopausal symptoms. J BiolSci 18(7):381-388. https://doi.org/10.3923/ jbs.2018.381.388

Freeman EW, Sammel MD, Lin H, Gracia CR, Pien GW, Nelson DB, Sheng L (2007) Symptoms associated with menopausal transition and reproductive hormones in midlife women. Obstet Gynecol 110(2 Pt 1):230-240. https://doi.org/10.1097/01.AOG.0000270153.59102.40

Freeman EW, Sammel MD, Lin H, Liu Z, Gracia CR (2011) Duration of menopausal hot flushes and associated risk factors. Obstet Gynecol 117(5):10951104. https://doi.org/10.1097/AOG.0b013e318214f0de

Hamidpour R, Hamidpour M, Hamidpour S, Shahlari M (2015) Cinnamon from the selection of traditional applications to its novel effects on the inhibition of angiogenesis in cancer cells and prevention of Alzheimer's disease, and a series of functions such as antioxidant, anticholesterol, antidiabetes, antibacterial, antifungal, nematicidal, acaracidal, and repellent activities. J Tradit Complement Med 5(2):66-70. https://doi. org/10.1016/j.jtcme.2014.11.008

Harrabi S, St-Amand A, Sakouhi F, Sebei K, Kallel H, Mayer P, Boukhchina S (2008) Phytostanols and phytosterols distributions in corn kernel. Food Chem 111(1):115-120. https://doi.org/10.1016/j.foodchem.2008.03.044

Hoffmann J, You H, Hedberg E, Jordan J, McClintock M (2014) Prevalence of bacterial vaginosis and Candida among postmenopausal women in the 
United States. J Gerontol B Psychol Sci Soc Sci 69(2):S205-S214. https:// doi.org/10.1093/geronb/gbu105

Jessica Elizabeth T, Gassara F, Kouassi A, Brar S, Belkacemi K (2017) Spice use in food: properties and benefits. Crit Rev Food Sci Nutr 57(6):1078-1088. https://doi.org/10.1080/10408398.2013.858235

Kamatou G, Vermaak I, Viljoen A (2012) Eugenol from the remote Maluku Islands to the international market place: a review of a remarkable and versatile molecule. Molecules 17(6):6953-6981

Kuhnle G, Dell'Aquila C, Aspinall S, Bingham S (2009) Phytoestrogen content of cereals and cereal-based foods consumed in the UK. Nutr Cancer 61(3):302-309. https://doi.org/10.1080/01635580802567141

Lecomte S, Demay F, Ferrière F, Pakdel F (2017) Phytochemicals targeting estrogen receptors: Beneficial rather than adverse effects? Int J Mol Sci 18(7):1381-1399. https://doi.org/10.3390/ijms18071381

Lethaby A, Marjoribanks J, Kronenberg F, Roberts H, Eden J, Brown J (2013) Phytoestrogens for menopausal vasomotor symptoms. Cochrane Database Syst Rev 12:1395. https://doi.org/10.1002/14651858.CD001395

Mansikkamaki K, Raitanen J, Malila N, Sarkeala T, Mannisto S, Fredman J et al (2015) Physical activity and menopause-related quality of life-a population-based cross-sectional study. Maturitas 80(1):69-74. https:// doi.org/10.1016/j.maturitas.2014.09.009

March CM, Goebelsmann U, Nakamura RM, Mishell DR (1979) Roles of estradiol and progesterone in eliciting the midcycle lutenizing hormone and follicle stimulating hormone surges. J Clin Endo Metab 49:507-513

Mishra N, Srivastava R (2020) Therapeutic and pharmaceutical potential of cinnamon. Therapeutic and pharmaceutical potential of cinnamon. In: Ethnopharmacological investigation of indian spices. Chapter 10, pp. 124-136. https://doi.org/10.4018/978-1-7998-2524-1.ch010

Mittal M, Gupta N, Parashar P, Mehra V, Khatri M (2014) phytochemical evaluation and pharmacological activity of syzygium aromaticum: a comprehensive review. Int J Pharm Pharm Sci 6(8):67-72

Moaty MI, Fouad S, El Shebini SM, Kazem Y, Ahmed NH, Mohamed MS, Hussein AS, Arafa A, Hanna LM, Tapozada ST (2015) Serum ceramide kinase as a biomarker of cognitive functions, and the effect of using two slimming dietary therapies in obese middle aged females. Maced J Med Sci 3(1):18-25. https://doi.org/10.3889/oamjms.2015.030

Moilanen J, Aalto A, Hemminki E, Aro A, Raitanen J, Luoto R (2010) Prevalence of menopause symptoms and their association with lifestyle among Finnish middle-aged women. Maturitas 67(4):368-374. https://doi. org/10.1016/j.maturitas.2010.08.007

Nassar M, Gaara A, El-Ghorab A, Farrag A, Shen H, Huq E, Mabry T (2007) Chemical constituents of clove (Syzygium aromaticum, Fam. Myrtaceae) and their antioxidant activity. Revista Latinoamericana de Química 35(3):47-58

North American Menopause Society (2004) Treatment of menopause-associated vasomotor symptoms: position statement of The North American Menopause Society. Menopause 11(1):11-33. https://doi.org/10.1097/01. GME.0000108177.85442.71

Patel S (2015) Plant essential oils and allied volatile fractions as multifunctional additives in meat and fish-based food products: a review. Food Addit Contam Part A Chem Anal Control Exposure Risk Assess 32(7):1049-1064. https://doi.org/10.1080/19440049.2015.1040081
Pimenta F, Leal I, Maroco J, Ramos C (2011) Perceived control, lifestyle, health, socio-demographic factors and menopause: impact on hot flashes and night sweats. Maturitas 69(4):338-342. https://doi.org/10.1016/j.matur itas.2011.05.005

Pinto E, Vale-Silva L, Cavaleiro C, Salgueiro L (2009) Antifungal activity of the clove essential oil from Syzygium aromaticum on Candida, Aspergillus and dermatophyte species. J Med Microbiol 58(11):1454-1462. https:// doi.org/10.1099/jmm.0.010538-0

Politi MC, Schleinitz MD, Col NF (2008) Revisiting the duration of vasomotor symptoms of menopause: a meta-analysis. J Gen Intern Med 23(9):15071513. https://doi.org/10.1007/s11606-008-0655-4

Ratcliffe W, Carter G, Dowsett M, Hillier S, Middle J, Reed M (1988) Oestradiol assays: applications and guidelines for the provision of a clinical biochemistry service. Ann Clin Biochem 25(Pt. 5):466-483

Rebar R, Erickson G, Yen S (1982) Idiopathic premature ovarian failure: clinical and endocrine characteristics. Fertil Steril 37(1):35-41

Schneider H, Heinemann L, Rosemeier H, Potthoff P, Behre H (2000) The Menopause Rating Scale (MRS) reliability of scores of menopausal complaints. Climacteric 3:59-64

Sheng S, Li T, Liu R (2018) Corn phytochemicals and their health benefits. Food Sci Human Wellness 7(3):185-195. https://doi.org/10.1016/j. fshw.2018.09.003

Sussman M, Trocio J, Best C (2015) Prevalence of menopausal symptoms among mid-life women: findings from electronic medical records. BMC Women's Health 15:58-63

Swerdloff R, Wang C (2008) Free testosterone measurement by the analog displacement direct assay and new evidence. Clin Chem 54(3):458-460

Tan MN, Kartal M, Guldal D (2014) The effect of physical activity and body mass index on menopausal symptoms in Turkish women: a crosssectional study in primary care. BMC Womens Health 14(1):38. https://doi. org/10.1186/1472-6874-14-38

Tseng L, El Khoudary S, Young E, Farhat G, Sowers M, Sutton-Tyrrell K et al (2012) The association of menopause status with physical function: the Study of Women's Health Across the Nation. Menopause 19(11):11861192. https://doi.org/10.1097/gme.0b013e3182565740

Wineinger M, Bemis M, Cuddy C, Willits A, May C (2013) From starch to bioproducts: the evolution of products of the corn refining industry. Corn Starch Washington, DC. Corn Refiners Association Annual report, www. corn.org consulted

Xu J, Chang C (2007) A comparative study on phenolic profiles and antioxidant activities of legumes as affected by extraction solvents. J Food Sci 72:S159-S166

Zeleke BM, Bell RJ, Billah B, Davis SR (2016) Vasomotor and sexual symptoms in older Australian women: a cross-sectional study. Fertil Steril 105(1):14955.e1. https://doi.org/10.1016/j.fertnstert.2015.09.017

\section{Publisher's Note}

Springer Nature remains neutral with regard to jurisdictional claims in published maps and institutional affiliations.

\section{Submit your manuscript to a SpringerOpen ${ }^{\circ}$ journal and benefit from:}

- Convenient online submission

- Rigorous peer review

- Open access: articles freely available online

- High visibility within the field

- Retaining the copyright to your article

Submit your next manuscript at $\boldsymbol{\nabla}$ springeropen.com 